DOI: https://doi.org/10.32839/2304-5809/2021-9-97-11

УДК 130.2:7.097/7.091.4

Максимов 6.I.

Херсонський осередок Національної спілки кінематографістів України

Лебедева Н.А.

Міжнародна Кадрова Академія (м. Київ);

Свразійська Академія телебачення і радіо

\title{
УКРАЇНСЬКИЙ АМАТОРСЬКИЙ КІНЕМАТОГРАФ В КОНТЕКСТІ СВРОПЕЙСЬКОГО КУЛЬТУРНОГО ПРОСТОРУ
}

Анотація. Аматорське кіно стало особливим видом самодіяльної творчості, мета якої є кіноосвіта і кінопросвітницька робота, вплив через художні засоби кіномистецтва на свідоме сприйняття художніх творів, ознайомлення 3 його образною мовою. В ході нашого дослідження нами виявлено та проаналізовано друковані та електронні джерела, проглянуто значну кількість аматорських кіноробіт і вперше описано їх особливості під кутом зору мистецтвознавства. Розглянуто аматорське кіно як особливий вид самодіяльної творчості та описано тематичні та художньо-стильові особливості українських конкурсних кінофільмів XVI Miжнародного кінофрестивалю аматорського кіно «Кінокімерія 2021». Аматорська кінотворчість потребує державної підтримки (фінансової, матеріально-технічної, інтелектуальної), що буде сприяти їі розвитку як унікального феномену національної культури, самобутньої творчості та самореалізації учасників процесу кінотворчості. Ключові слова: кіномистецтво, культура, фестиваль, міжнародний, аматорське, UNICA, Кінокімерія.

\section{Maksimov Evgen}

Kherson Branch of the Ukrainian Association of Cinematographers

Lebyedyeva Nadya

International Personnel Academy in Kyiv, Eurasian Academy of Television and Radio

\section{UKRAINIAN AMATEUR CINEMATOGRAPHY IN THE CONTEXT OF THE EUROPEAN CULTURAL SPACE}

Summary. Amateur movie has become a special kind of amateur art, the purpose of which is film education, the influence through the artistic means of cinematography on the conscious perception of artworks, acquaintance with its figurative language. In the course of our research, we identified and analyzed printed and electronic sources, reviewed a significant number of amateur films and for the first time described their features from the point of view of art history. The main aim of the article is to consider the amateur movie as a special kind of art and to describe thematic, artistic and stylistic features of Ukrainian amateur competitive films of the XVI International Amateur Film Festival «Kinokimeria 2021»). The proposal of the Ukrainian delegation to hold the 84th UNICA Festival in Ukraine was unanimously accepted at the UNICA Congress, which took place within the framework of the 81st Festival. Conclusions and suggestions: amateur filmmaking needs state support (financial, logistical, intellectual), which will contribute to its development as a unique phenomenon of national culture, original creativity and self-realization of participants in the filmmaking process. There are some applied methods such as structural analysis, comparative, synthesis, empirical method, as a result of reviewing the competition program, personal presence confirmed the intention to hold one of the most interesting cultural events of European significance in Ukraine. The authors of the study concluded that amateur cinema will promote the integration of national art into the European context, provide a presentation of the best national traditions, establish cultural communications, intensify the exchange of experiences in the field. It's also approved that the Kherson region has all the possibilities and sufficient potential to host a festival at the European level.

Keywords: cinematography, culture, festival, international, amateur, UNICA.

Постановка проблеми. Паралельно до процесу становлення та розвитку масової кіноіндустрії, яка орієнтувалась на прокат в кінотеатрах чисельних копій одного фрільму, новий імпульс розвитку отримало малобюджетне кіно, яке зосередило увагу на творчі експерименти, залучало непрофресійних акторів, режисерів, кінооператорів. В його основі - бажання людини творчо виявити себе, зафіксувати хроніку важливих подій власного життя, передати палітру почуттів, переживань, сподівань.

Аматорське кіно стало особливим видом самодіяльної творчості, мета якої є кіноосвіта і кінопросвітницька робота, вплив через художні засоби кіномистецтва на свідоме сприйняття художніх творів, ознайомлення $з$ його образною мовою.

Аналіз останніх досліджень і публікацій. В ході нашого дослідження нами виявлено та проаналізовано друковані та електронні джерела, проглянуто значну кількість аматорських кіноробіт і вперше описано їх особливості під кутом зору мистецтвознавства. Важливий корпус джерел складають законодавчі документи, галузеві стандарти, які визначають правове поле фрункціонування кінотворчості $[13 ; 14 ; 19]$.

В ході дослідження ми спирались на монограdiï, навчальні посібники та підручники. Серед них відмітимо: «Кіномистецтво» Л. Брюховецької [2] та «Вступ до спещіальності кіно- телемистецтво» С. Горевалова та Г. Десятника [5], в яких розкриті теоретичні аспекти та практичні засади кіномистецтва та кіновиробництва; посібник В. Монастирського «Кіномистецтво в соціокультурній роботі» [11], в якому розглядаеться специфіка і можливості кіномистецтва як засобу соціокультурної роботи, організацію їі змісту та форми 3 різними 
категоріями споживачів культурного продукту; інформативним з точки зору дослідження кінофрестивалю як масштабного івент-проекту є посібники з івент-менеджменту - В. Бабкова «Фестивальный менеджмент» [1], Л. Зеленської «Івент-менеджмент» [6], А. Назимко «Событийный маркетинг» [12], Н. Федотової «Менеджмент в сорере культуры» [15], У. Хальцбаура «Event-менеджмент» [16], Шмидта Б. «Бизнес в стиле шоу» [17], А. Шумовича «Великолепные мероприятия: технологии и практика event management» [18], Є. Жュданової «Основи арт-менеджмента» [7] та ін.

Виділення не вирішених раніше частин загальної проблеми. У XX ст. українське кіномистецтво активно заявило про себе як мистецтво високої естетичної наснаженості, мистецтво, яке дає можливість відчути живий суперечливий i водночас яскраво цілісний процес культурного життя. Зберігаючи зв'язок із традиціями народної творчості минулого, сучасне вітчизняне мистецтво набуває нового змісту, нових якостей і рис.

Активізуються процеси в аматорському середовищі, в усіх фрормах культурної самодіяльності, які сприяють розвитку народної творчості та самовираженню широких верств, що є виразниками певних мистецьких течій, носіями культурних традищій, естетичних уподобань тощо.

Таким чином, досліджуючи кіноаматорство, як один із видів народної творчості, на відміну від професійного кіно, ми тим самим визначаємо його унікальність у масовості.

Мета статті - розглянути аматорське кіно як особливий вид самодіяльної творчості та описати тематичні та художньо-стильові особливості українських конкурсних кінофільмів XVI Міжнародного кінофрестивалю аматорського кіно «Кінокімерія 2021».

Виклад основного матеріалу. Впродовж багатьох років фрранцузи брати Люм'ер вважалися родоначальниками кіномистецтва, але маємо повідомлення про інший виток зародження кінофрільму, що підтверджено українськими вченими. У своїй книзі «Культурологія мистецтва» вчена зазначає: «Як відомо, перший загальнодоступний сеанс кінематографра відбувся 28 грудня 1895 р. у Парижі. Саме в цей день брати О. та Л. Люм'єр продемонстрували свою першу кінопрограму, що мала коротенькі документальні замальовки: «Вихід робітників із фрабрики», «Прибуття поїзда» та ін. Одначе ще раніше 1893 р. одеський винахідник Й. Тимченко створив апарат для знімання рухомих об'єктів і на IX з'їзді російських природознавців у Москві продемонстрував публіці свої фрільми: “Списометальники» та «Вершники», тривалість кожного 3 них - 1 хвилина [8, с. 80]. 30 вересня 1896 р. було знято перший фрільм в Україні. Цю дату офіщійно вважають датою народження вітчизняного кіно. Тоді фотографр А. Федецький відтворив на плівщі момент перенесення чудотворної ікони Божої Матері до харківського Покровського монастиря. Того ж року, 2 грудня, цю хроніку публічно продемонстрували в Харківському оперному театрі. Це були перші знімання в царській Росії, які демонструвалися у всьому світі [8, с. 81].

Доктор філософрьких наук С. Безклубенко у своїй книзі «Українське кіно: начерк історії описуе вищезгаданий фракт наступним чином: «Піонери вітчизняного кінематографу - Й. Тимченко; А. Фе- децький - в Україні, М. Акимов, Сашин-Федоров у Великоросії - були у своїй творчості цілком на рівні епохи. Харків'янин Й.Тимченко (1852-1924) на винайденому ним ще 1893 року апараті відзняв і демонстрував фрільми у січні 1895 р. - майже на цілий рік раніше в інституті фотографії при Академії мистецтв у Відні, та В. Сашин-Федоров, відомий російський актор, здійснив перші зйомки в середині 1896 року. Неодноразово нагороджені на міжнародних виставках, вони, однак через відсутність коштів, припинили зйомки і лише значно пізніше, коли почалось уже промислове вітчизняне кіновиробництво, Тимченко та Сашин-Федоров повернулись у кінематограф [3, с. 17].

Отже, можемо сказати, що перші кінематографрісти також були аматорами, бо вони любили цю справу, а термін «аматорський» запозичений, і не кожне академічне видання має у своєму арсеналі це визначення. Детальніше про термін дивиться у публікащії, щодо кіноаматорства [10].

До початку світових подій, що пов'язані з пандемією COVID-19, 20 вересня 2018 року заступник Міністра культури України Юрій Рибачук провів робочу зустріч з Президентом UNICA Дейвом Ваттерсоном. У зустрічі також взяли участь представники Державного агентства України з питань кіно, Міністерства закордонних справ України та Херсонської ОДА. Під час спілкування були обговорені основні питання, пов'язані з можливістю організащії та проведення у 2022 році в Україні 84-го Міжнародного фрестивалю непрофесійного і незалежного кіно UNICA.

UNICA - Міжнародний союз кіно, член Міжнародної ради кіно, телебачення та аудіовізуальних комунікащій при ЮНЕСКО, створено у 1931 рощ. Об'еднуе асоціації: спілки, кіноклуби кіноаматорів і незалежних кінематографрістів 35-ти країн світу (Свропа, Америка, Азія і Африка). Щороку (крім років Другої світової війни та часів відбудови Європи) проводиться Міжнародний кінодестиваль непрофесійного кіно у різних країнах, які є офріпійними членами UNICA. В серпні 2019 року в Нідерландах (м. Зейст) відбувся 81-й Міжнародний фрестиваль UNICA, 82-й фестиваль заплановано провести у Великій Британії (м. Дортмунд), 83-й у Польщі (м. Варшава). На конгресі UNICA, який відбувся в рамках 81-го фестивалю була одноголосно прийнята пропозиція делегащії України провести 84-й фрестиваль UNICA в Україні [9, с. 4]. Бернхард Ліндер у своєму листі до Свгена Максимова (одного з авторів даної статті) зауважив, що у 2020 та 2021 роках UNICA неможливо було провести. «За цей час ми дуже інтенсивно шукали можливості та планували майбутні події. Тим часом ми отримали кілька пропозищй щодо проведення фестивалю UNICA у Швейцарії у 2022 році. На џому фестивалі ми представимо нову форму UNICA. Італія подала заявку на проведення UNICA у 2023 році. Ми були б дуже щасливі, якби в 2024 році у нас була б можливість проведення UNICA в Україні» [9, с. 5].

Перед відкриттям кінофестивалю в Херсонській обласній універсальній науковій бібліотеці ім. О. Гончара відбулась прес-конференція за участю віце-президента UNICA Анджея Пшездзецького, виконуючого обов'язки директора Департаменту реалізації гуманітарної політики ХОДА Ігоря Мазура, голови журі, кіноакадеміка і голови Спілки кінокритиків України Воло- 
димира Войтенко, художнього керівника курсу операторської майстерності, Заслуженого діяча мистецтв України і члена Правління Української кіноакадемії Сергія Борденюка, Заслуженого працівника культури, профоксора КНУ театру, кіно і телебачення ім. І. Л. Карпенко-Карого Юрія Ріпенко, заслуженого працівника культури і кінознавця Олени Пафренюк, сценариста і письменника Владислава Таранюка, члена Національної спілки кінематографістів України Сергія Уса. В ході спілкування 3 представниками телевізійних каналів та журналістів було підтверджено вагу українського аматорського кінематографру в площині Свропейського культурного надбання i акцентовано на проведенні UNICA в Україні у Херсонській області. Після прес-конференщії поважні гості відправились до Херсонської обласної державної адміністрації з метою участі в круглому столі з представниками влади щодо обговорення деталей співробітництва з европейськими колегами та підготовки даної культурної події.

Отже, з 10 по 12 вересня 2021 року у м. Скадовськ Херсонської області відбувся XVI Міжнародний кінодестиваль аматорського кіно «Кінокімерія». Географрія традиційно охоплює не тільки Україну. Було представлено кінороботи з Канади, Ірану, Індіі, Аргентини, Польщі, Киргизії, Китаю, Казахстану.

Переможцем фестивалю став документальній фрільм Олени Мудрої, Наталії Музичук, Степана Градового з Тернопільської області «Орнаменти долі» (хронометраж 14:08). Ця робота присвячена трагічним сторінкам історії України - депортації українців 9 вересня 1944 року на територію Польщі. Спогади депортованого до Краківського воєводства О. Венгировича, а також В. Шлятна, С. Кринищького, С. Ванат, М. Тиханського супроводжуються фотографріями та піснями, показом народних промислів. Стефран Криницький читає молитву, яку читали депортовані рідні, а Степанія Медух записала 50 лемківських пісень. Емоційну складову композиції фрільму посилено документальними відеофрагментами фрільму «Акція Вісла».

«Заещь на ім'я Маск» Студія «Крок» (06:15) автор фрільму: Українець Олена, керівник студії: Іванов Юрій Вселодович. На планеті Земля зайці з'їли всю моркву. Заєць космонавт на імя Маск відправився на пошук нових плаунет, на яких можна буде вирощувати моркву. Йому спочатку дуже не щастило, але він був оптимістом і продовжував свої пошуки. І... все вдалося!» [9, с. 19]. Яскраві дитячі малюнки захоплюють глядача барвистою композицією. Цікаві епізоди, де на ненаселених планетах із зерен, висаджених зайцем виростає щось агресивне, франтастичних форм. Космічному кораблеві ледь-ледь вдається покинути такі планети. Ритм кінороботи дотриманий у повторюваних діях головного героя, у поєднанні драрб (техніка гуаші). Зворушлива емоційна складова фрільму: великий план мордочки зайця, коли він з сумом дивиться на зірки, туди, де залишилася рідна Земля.

«Напад хутряної риби» [9, с. 20] автор фрільму: Шинкаренко Анастасія, НВК, студія «КРОК», керівник студії: Іванов Юрій Всеволодович. Малюнками олівцями зображено сюжет спасіння маленьких совенят невідомою твариною, яка виявляеться рибою, що повернула їх з річки до рідного гнізда.
Мультиплікаційна робота «Подорож» (04:09) НВК, студія КРОК, автора Земик Захар, керівник студії: Іванов Юрій Всеволодович [9, с. 21] цікава складнощами виконання малюнків технікою акварелі. Філософрське-емоційно наповнено роботу музичними засобами, коли душі загиблих у катастрофі летять до Луни.

Цікава мультиплікаційна робота «Спритні зайці» автор: Українець Олена, НВК, студія КРОК, керівник - Ю. В. Іванов. Яскраво виконані гуашшю дитячі малюнки, що зображують зайців. Один заєць їв бургери і пив Кока-Колу, другий газовану воду, солодку та «нездорову їжу», а третій споживав смачну моркву. Змагання зайців показуе справжню цінність їжі. "Смачна і корисна для здоров'я їжа - запорука успіху в будь-якій справі! Це знають не тільки люди, але і зайці!» [9, с. 21].

Цікавою за технікою виконання є мультиплікаційна роботі «Тіньове сяйво». За допомогою олівців автор фрільму Назар Голомутько намагається створити складну фрілософрську роботу, осмислюючи реальне та уявне, шлях души, людські почуття та емоції. «Фільм про світ франтазій і реальність. Перед головним героєм стоїть важке для кожної людини питання про те, що ж все-таки краще, не справжній світ, в якому все ідеально, або ж сувора реальність, що не робить нікому поблажок» [9, с. 22]. Композицію роботи побудовано ритмічно, цікаві перетини ліній, геометричні фрігури, що також створюють ритм, підкреслюючи сюжетне наповнення мультфільму.

Ігровий фрільм «День рибалки» (Міська станція юних техніків м. Миколаїв, автор: Ірина Кузьмич, керівник студії: І. С. Гузій, хронометраж 06:35) [9, с. 22]. Ретельно готується хлопець на рибалку. Кожен кадр виважений і має композиційну побудову. 3 гумором автори фрільму показують ситуацію, коли дівчатка мають вдачу, а хлопець намагається це зрозуміти. Дівчина з радістю готова розповісти про свій секрет. Фільм цікаво дивитись завдяки гумору та композиції.

Цікавою роботою вважаємо соціально спрямований фрільм Єлизавети Вільдяевої 3 м. Волноваха Донецької області "Вір в добро» (керівник О. В. Назарок, хронометраж 04:08). Ми живемо у складні часи, коли души людей, здаються черствими, кимось керує гординя, або бажання поставити себе вище когось. Але є добро і воно перемагає, добро в душі одніеї людини здатне творити чудо. Зробити хоча б одну людину щасливою це чудо! Кожен кадр виважений, має правильну композиційну побудову і сприяє емоціональності передачі думки автору фрільму глядачеві. В каталозі фестивалю читаємо: «Осінь холодно, сиро, вулиця... Самотня безпритульна дівчинка. Перехожі поводяться по-різному, хто з співучастю, хто просто проходить повз. Молода жінка зупиняеться, замислюеться і приймає рішення... забирає дівчинку з собою» [9, с. 13]. Фільм має тільки музичний супровід, що підкреслюе фрілософрський настрій всієї роботи. Він дійсно торкаеться душі.

Висновки і пропозиції. В результаті перегляду конкурсних робіт, вивчення наукових джерел автори даної статті вважають, що фестиваль аматорського кіно «Кінокімерія» став френоменом медіаменеджменту України, впродовж свого існування зіграв значну роль в інтеграції українського медіапростору та формуванні нової сус- 
пільної свідомості, культурно-мистецьких потреб та художніх смаків широких верств. Аматорська кінотворчість потребує державної підтримки (фінансової, матеріально-технічної, інтелектуальної), що буде сприяти їі розвитку як унікального френомену національної культури, самобутньої творчості та самореалізації учасників процесу кінотворчості. Це, у свою чергу, надасть можливість залучити до кіноаматорства широкі суспільні верстви, насамперед молодь, та формувати естетичні смаки, мистецькі уподобання та пріоритети. Це сприятиме інтеграції національного аматорського мистецтва в європейський контекст, забезпечить представлення кращих національних традицій, встановить культурні комунікації, активізує процеси обміну досвідом в галузі.

\section{Список літератури:}

1. Бабков В. Фестивальный менеджмент. Москва : ART-менеджер, 2007. 426 с.

2. Безклубенко С.Д. Українське кіно: Начерк історії. Київ, 2001. 118 с.

3. Брюховецька Л. Кіномистецтво : навч. посібник. Київ : Логос, 2011. 391 с.

4. Госейко Л. Історія українського кінематографра. 1896-1995 / пер. с фpр. Пер. Станіслав Довганюк. Відп. ред. i передм. Володимир Войтенко. Київ : КІNO-КОЛО, 2005. 464 с.

5. Горевалов С.І., Десятник Г.О. Вступ до спеціальності кіно- телемистецтво : навч. посібник. Київ : КНУ, 2014.132 с.

6. Зеленська Л. Івент-менеджмент: словник-довідник організатора заходів. Київ : НАКККіМ, 2015.84 с.

7. Жданова Е.И. Основы арт-менеджмента : учеб. пособие. Москва : Моск. гос. унив-т культуры и искусств, 2008. $116 \mathrm{c}$

8. Ігошкіна Н.Г. Культурологія мистецтва. Київ : МАУП, 2005. 208 с.

9. Каталог. Кінокімерія. XVI міжнародний кінофестиваль 10-12 вересня 2021. Херсон, 2021. 47 с.

10. Лебедева Н.А. Фильмы-победители XIV Международного кинофестиваля аматорского кино «Кинокиммерия 2019». Молодий вчений. 2019. № 10. C. 61-64. URL: http://molodyvcheny.in.ua/files/journal/2019/10/14.pdf

11. Монастырский В.А. Киноискусство в социокультурной работе : Учеб. пособие. Тамбов : Из-во Тамб. ун-та, 1999. $147 \mathrm{c}$

12. Назимко А. Событийный маркетинг. Москва : Вершина, 2007. 224c.

13. Про кінематографрію : Закон України від 13.01.1998 р. № 9/98-ВР // Відом. Верхов. Ради України. 1998. № 22. Ст. 114. (Поточ. ред. від 12.12.2012 на підставі № 5461-17).

14. Про культуру : Закон України від 14.12.2010 р. № 2778-17 // Офіц. Вісн. України. 2011. № 2. С. 13. Ст. 91. (Поточ. ред. від 12.12.2012 р. на підставі № 5461-17).

15. Федотова Н.Г. Менеджмент в сфере культуры : учеб. пособие. В.-Новгород : НовГУ, 2015. 282 с.

16. Хальцбаур У. Event-менеджмент: профессиональная организация мероприятий. Event-менеджмент. Москва : ЭКСМО, 2010. 384 с.

17. Шмидт Б. Бизнес в стиле шоу. Маркетинг в культуре впечатлений / Б. Шмидт, Д. Роджерс, К. Вроцес. Москва : Вершина, 2005. 400 с.

18. Шумович А. Великолепные мероприятия: технологии и практика event management. Москва : Изд-во «Манн, Иванов и Фербер», 2007. 336 с.

19. Ian Yeoman. Festival and Events Management. Москва, 2010. 448 с.

\section{References:}

1. Babkov V. (2007) Festyvalnyi menedzhment [Festival management]. Moscow: ART-manager. (in Russian)

2. Bryuxoveczka L. (2011) Kinomystecztvo [Cinema Art]. Kyiv: Logos. (in Ukrainian)

3. Bezklubenko S.D. (2001) Ukrainske kino: Nacherk istorii [Ukrainian cinema: A sketch of history]. Kyiv. (in Ukrainian)

4. Hoseiko L. (2005) Istoriia ukrainskoho kinematohrafa. 1896-1995 [History of Ukrainian cinema. 1896-1995]. Kyiv: KINO-KOLO. (in Ukrainian)

5. Horevalov S.I., Desiatnyk H.O. (2014) Vstup do spetsialnosti kino- telemystetstvo [Introduction to the specialty of film and television]. Kyiv: KNU. (in Ukrainian)

6. Zelenska L. (2015) Ivent-menedzhment: slovnyk-dovidnyk orhanizatora zakhodiv [Event management: dictionaryguide of the organizer of events]. Kyiv: NAKKKiM. (in Ukrainian)

7. Zhdanova E.Y. (2008) Osnovy art-menedzhmenta [Fundamentals of art management] Moscow: Moscow State University of Culture and Arts. (in Russian)

8. Ihoshkina N.H. (2005) Kulturolohiia mystetstva [Culturology of art]. Kyiv: MAUP. (in Ukrainian)

9. Kataloh. Kinokimeriia (2021) XVI mizhnarodnyi kinofestyval 10-12 veresnia 2021 [Catalog. XVI International Film Festival September 10-12, 2021]. Kherson. (in Ukrainian)

10. Lebedeva N.A. (2019) Fylmy-pobedytely XIV Mezhdunarodnoho kynofestyvalia amatorskoho kyno «Kynokymmeryia 2019» [Films-winners of the XIV International Amateur Film Festival «Kinokimmeriya 2019»]. Young Scientist, no. 10, pp. 61-64. Available at: http://molodyvcheny.in.ua/files/journal/2019/10/14.pdf (accessed 14 September 2021).

11. Monastyrskyi V.A. (1999) Kynoyskusstvo v sotsyokulturnoi rabote [Cinema in socio-cultural work]. Tambov. (in Russian)

12. Nazymko A. (2007) Sobytyinyi marketynh [Event marketing]. Moscow: Vershina. (in Russian)

13. Pro kinematohrafiiu: Zakon Ukrainy vid 13.01.1998 r. № 9/98-VR // Vidom. Verkhov. Rady Ukrainy. 1998 . № 22. St. 114. (Potoch. red. vid 12.12.2012 na pidstavi № 5461-17).

14. Pro kulturu: Zakon Ukrainy vid 14.12 .2010 r. № 2778-17 // Ofits. Visn. Ukrainy. 2011. № 2. S. 13. St. 91. (Potoch. red. vid 12.12.2012 r. na pidstavi № 5461-17).

15. Fedotova N. H. (2015) Menedzhment $v$ sfere kultury [Management in the field of culture] V.-Novhorod: NovHU. (in Russian)

16. Khaltsbaur U. (2010) Event-menedzhment: professyonalnaia orhanyzatsyia meropryiatyi [Event management: professional organization of events. Event management]. Moscow: EXMO. (in Russian)

17. Shmydt B. (2005) Byznes v style shou. Marketynh v kulture vpechatlenyi [Business in the style of the show. Marketing in the culture of impressions]. Moscow: Vershyna. (in Russian)

18. Shumovych A. (2007) Velykolepnye meropryiatyia: tekhnolohyy y praktyka event management [Great events: technology and event management practices]. Moscow: Mann, Ivanov and Ferber Publishing House. (in Russian)

19. Ian, Yeoman (2010) Festival and Events Management. Moscow. 